Prepared in cooperation with the City of Kansas City, Missouri

Flood-Inundation Maps for the Blue River near Red Bridge Road, Kansas City, Missouri, 2019

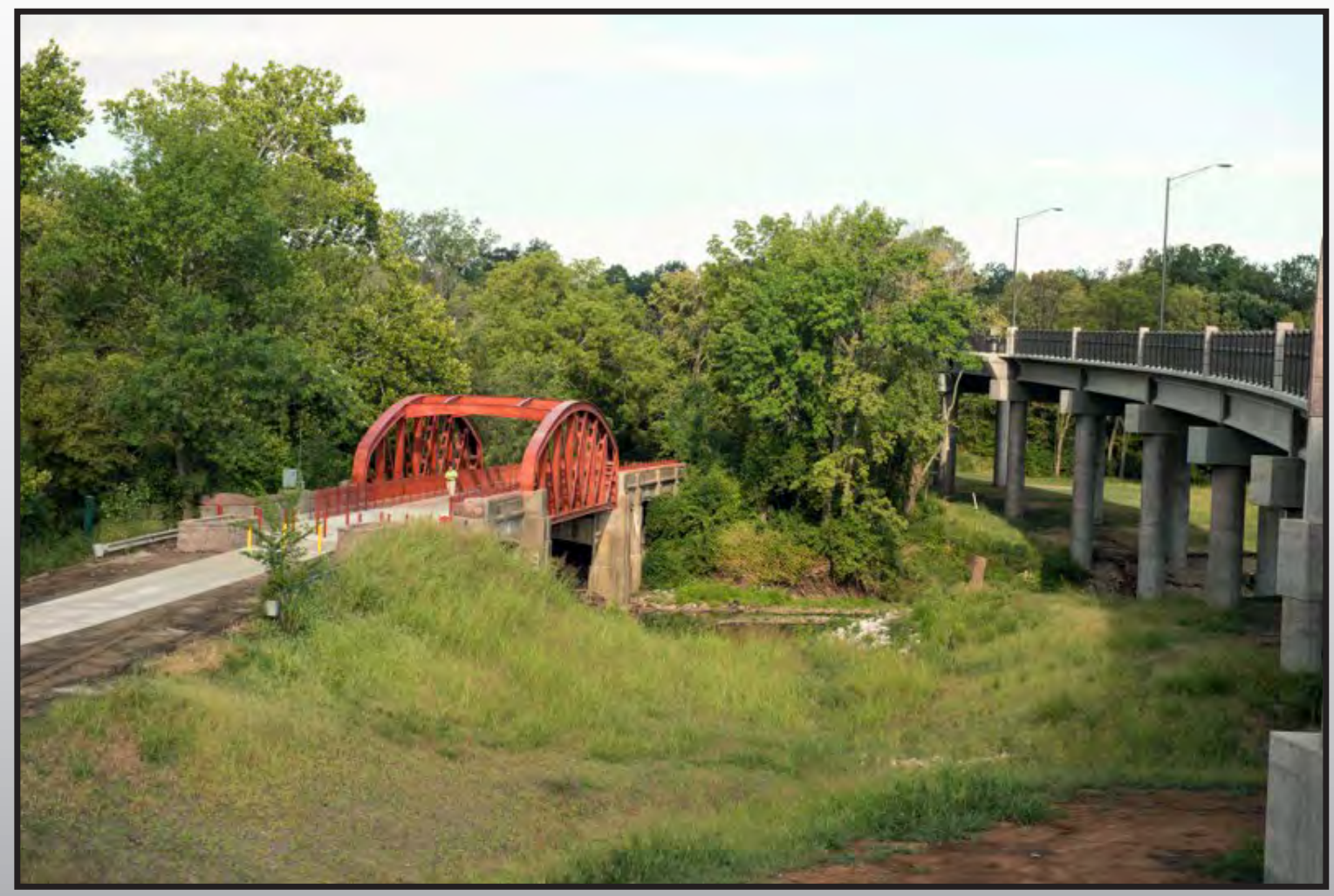

Scientific Investigations Report 2020-5057 
Cover photograph. Old Red Bridge (left) and new Red Bridge Road (right) bridges over the Blue River in Kansas City, Missouri (USGS streamgage Blue River at Red Bridge Road is located on the downstream side of the new bridge). Photograph by David Remley, City of Kansas City, Parks and Recreation Department, used with permission. 


\section{Flood-Inundation Maps for the Blue River near Red Bridge Road, Kansas City, Missouri, 2019}

By David C. Heimann, Jonathon D. Voss, and Paul H. Rydlund, Jr.

Prepared in cooperation with the City of Kansas City, Missouri

Scientific Investigations Report 2020-5057 


\section{U.S. Geological Survey, Reston, Virginia: 2021}

For more information on the USGS - the Federal source for science about the Earth, its natural and living resources, natural hazards, and the environment—visit https://www.usgs.gov or call 1-888-ASK-USGS.

For an overview of USGS information products, including maps, imagery, and publications, visit https://store.usgs.gov/.

Any use of trade, firm, or product names is for descriptive purposes only and does not imply endorsement by the U.S. Government.

Although this information product, for the most part, is in the public domain, it also may contain copyrighted materials as noted in the text. Permission to reproduce copyrighted items must be secured from the copyright owner.

Suggested citation:

Heimann, D.C., Voss, J.D., and Rydlund, P.H., Jr., 2021, Flood-inundation maps for the Blue River near Red Bridge Road, Kansas City, Missouri, 2019: U.S. Geological Survey Scientific Investigations Report 2020-5057, 14 p., https://doi.org/10.3133/sir20205057.

Associated data for this publication:

Heimann, D.C., Voss, J.D., and Rydlund, P.H., Jr., 2020, Geospatial datasets for the flood-inundation study of the Blue River near Red Bridge Road, Kansas City, Missouri, 2019: U.S. Geological Survey data release, https://doi.org/ 10.5066/P90MH291.

ISSN 2328-0328 (online) 


\section{Acknowledgments}

The authors wish to thank the local and Federal agencies that have cooperated in the funding for the operation and maintenance of the streamgages used for this study, especially the City of Kansas City, Missouri, and the U.S. Army Corps of Engineers. Special thanks are given to the City of Kansas City, Water Services Department, for their cooperation in this study and to the National Weather Service for their continued support of the U.S. Geological Survey floodinundation mapping initiative. 



\section{Contents}

Acknowledgments ……...................................................................................................................

Abstract

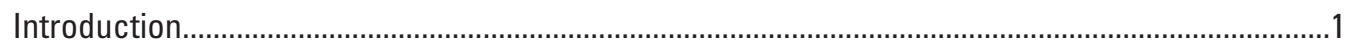

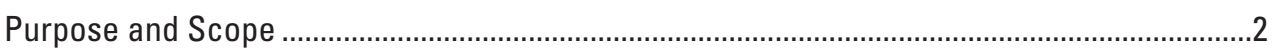

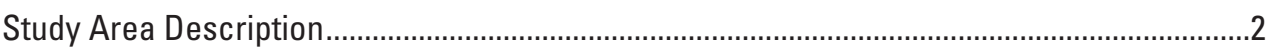

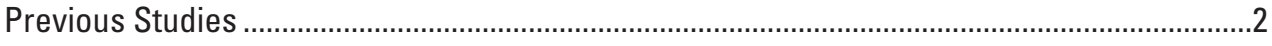

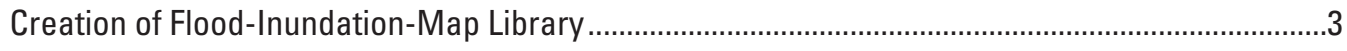

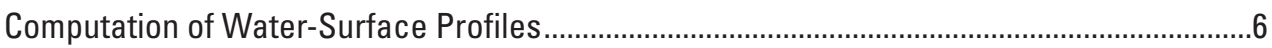

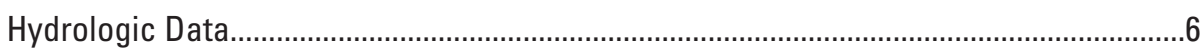

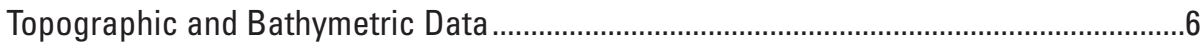

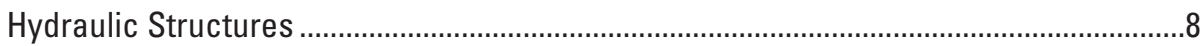

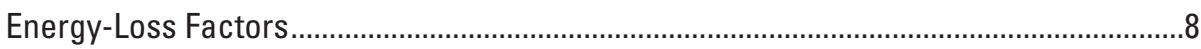

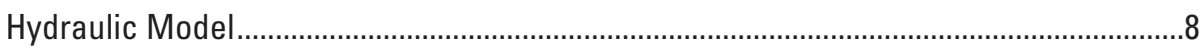

Development of Water-Surface Profiles .........................................................................

Development of Flood-Inundation Maps …………...........................................................

Flood-Inundation Map Delivery ...................................................................................

Disclaimer for Flood-Inundation Maps ........................................................................10

Uncertainties and Limitations Regarding Use of Flood-Inundation Maps ......................10

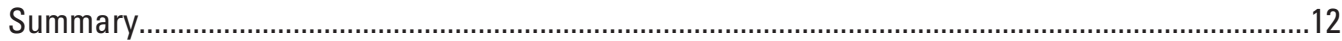

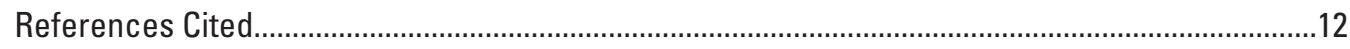

\section{Figures}

1. Map showing the Blue River Basin, streamgage locations, and extents of the flood-inundation mapping reaches from Heimann and others (2014), including the Blue River near Red Bridge Road map reach (reach 4) updated in this study ............3

2. Flood-inundation map showing the Blue River near Red Bridge Road study reach in Kansas City, Missouri, corresponding to a stage of 47.0 feet at the U.S. Geological Survey streamgage 06893195 at Red Bridge Road

\section{Tables}

1. U.S. Geological survey streamgage information for the Blue River Basin, Kansas City, Missouri, and vicinity

2. Peak streamflows for selected annual exceedance probabilities for the Blue River at Kansas City, Missouri

3. Estimated streamflows for corresponding stages and water-surface elevations at selected locations, used in the hydraulic model of the Blue River at Kansas City, Missouri.

4. Calibration of model to target water-surface elevations at U.S. Geological Survey streamgage 06893150, Blue River at Blue Ridge Boulevard Extension, Kansas City, Missouri.

5. Calibration of model to target water-surface elevations at U.S. Geological Survey streamgage 06893500, Blue River at Kansas City, Missouri.. 


\section{Conversion Factors}

U.S. customary units to International System of Units

\begin{tabular}{lcl}
\hline \multicolumn{1}{c}{ Multiply } & By & \multicolumn{1}{c}{ To obtain } \\
\hline foot $(\mathrm{ft})$ & Length & \\
mile $(\mathrm{mi})$ & 0.3048 & meter $(\mathrm{m})$ \\
& 1.609 & kilometer $(\mathrm{km})$ \\
\hline square mile $\left(\mathrm{mi}^{2}\right)$ & Area & \\
\hline & 2.590 & square kilometer $\left(\mathrm{km}^{2}\right)$ \\
\hline cubic foot per second $(\mathrm{ft} 3 / \mathrm{s})$ & Flow rate & \\
\hline
\end{tabular}

\section{Datum}

Vertical coordinate information is referenced to (1) stage, the height above an arbitrary datum established at a streamgage, and (2) elevation, the height above the North American Vertical Datum of 1988 (NAVD 88).

Horizontal coordinate information is referenced to the North American Datum of 1983 (NAD 83).

\section{Abbreviations}

$\begin{array}{ll}\text { AEP } & \text { annual exceedance probability } \\ \text { ALERT } & \text { Automated Local Elevation in Real Time } \\ \text { DEM } & \text { digital elevation model } \\ \text { FEMA } & \text { Federal Emergency Management Agency } \\ \text { GIS } & \text { geographic information system } \\ \text { HEC-RAS } & \text { Hydrologic Engineering Center's River Analysis System } \\ \text { lidar } & \text { light detection and ranging } \\ n & \text { Manning's roughness coefficient } \\ \text { NWS } & \text { National Weather Service } \\ \text { USACE } & \text { U.S. Army Corps of Engineers } \\ \text { USGS } & \text { U.S. Geological Survey }\end{array}$




\title{
Flood-Inundation Maps for the Blue River near Red Bridge Road, Kansas City, Missouri, 2019
}

\author{
By David C. Heimann, Jonathon D. Voss, and Paul H. Rydlund, Jr.
}

\section{Abstract}

Digital flood-inundation maps for a 4.6-mile reach of the Blue River near Red Bridge Road in Kansas City, Missouri, were created by the U.S. Geological Survey (USGS), in cooperation with the City of Kansas City, Missouri. The flood-inundation maps, which can be accessed through the USGS Flood Inundation Mapping Program website at https://www.usgs.gov/mission-areas/ water-resources/science/flood-inundation-mapping-fimprogram, depict estimates of the areal extent and depth of flooding corresponding to selected water levels (stages) at the USGS streamgage 06893195, Blue River at Red Bridge Road, Kansas City, Mo. Near-real-time stages at this streamgage may be obtained from the USGS National Water Information System at https://doi.org/10.5066/F7P55KJN or the Johnson County, Kansas, StormWatch Automated Local Elevation in Real Time Flood Warning System at https://www.stormwatch.com.

Flood profiles were computed for the Blue River reach by means of a one-dimensional model for simulating watersurface profiles with steady-state flow computations. The model was calibrated by using the current stage-streamflow relations at the upstream USGS streamgage 06893150, Blue River at Blue Ridge Boulevard Extension, Kansas City, Mo., and the downstream streamgage 06893500, Blue River at Kansas City, Mo.

The hydraulic model was then used to compute 37 watersurface profiles for flood stages at 1 -foot (ft) intervals referenced to the streamgage datum and ranging from $11 \mathrm{ft}$, or near bankfull, to $47 \mathrm{ft}$ at the reference streamgage 06893195 . The upper stage for the map library exceeds the stage corresponding to the estimated 0.2 -percent annual exceedance probability flood (500-year recurrence interval flood) in the model reach. The simulated water-surface profiles were then combined with a geographic information system digital elevation model with a maximum 10-centimeter vertical root mean square error and 4.0-ft horizontal resolution to delineate the area flooded at each water level.

The availability of these maps, along with real-time internet information regarding current stage from the USGS streamgage, will help guide emergency management personnel and residents in flood mitigation, preparedness and planning, flood-response activities such as evacuations and road closures, and any postflood recovery efforts.

\section{Introduction}

The city of Kansas City, Missouri, with an estimated 2018 population of about 492,000 (U.S. Census Bureau, 2020), has experienced moderate to major flooding from multiple sources including the Blue River on numerous occasions, most notably in 1951, 1961, 1977, 1984, 1990, 2010, and 2017 (National Weather Service [NWS], 2019a). These floods resulted in damages within Kansas City costing tens of millions of dollars and more than 25 casualties (U.S. Army Corps of Engineers [USACE], 1967; Hauth and others, 1981; NWS, 2019b). Floodplains within Kansas City are moderately to highly developed and contain a mix of residential and commercial structures. Flood-inundation maps were generated for sections of the Blue River and for selected tributaries in previous studies (Kelly and Rydlund, 2006; Kelly and Huizinga, 2008; Heimann and others, 2014). Emergency responders relied on these flood-inundation maps and other information sources to make decisions on how to best alert the public and mitigate flood damages. A second source of information is the Federal Emergency Management Agency (FEMA) flood insurance study for the City of Kansas City, dated January 20, 2017 (FEMA, 2017). A third source is the real-time stage data accessed for U.S. Geological Survey (USGS) streamgage 06893195, Blue River at Red Bridge Road, Kansas City, Mo. (USGS, 2020a), and Kansas City Automated Local Elevation in Real Time (ALERT) streamgage information (available at https://www.stormwatch.com/) from which current (2020) or historical water levels (stages) can be obtained.

Although the current stage at a USGS streamgage is particularly useful for residents near a streamgage, it is of limited use to residents farther upstream or downstream because the water-surface elevation is not constant along the entire stream reach. Knowledge of a water level at a streamgage is difficult to translate into depth and areal extent of flooding at points distant from the streamgage. One way to address these informational gaps is to produce a library of flood-inundation maps that are 
referenced to the stages recorded at the USGS streamgage. By referring to the appropriate map, emergency responders can discern the severity of flooding (depth of water and areal extent), identify roads that are or will soon be flooded, and make plans for notification or evacuation of residents in harm's way for some distance upstream and downstream from the streamgage. In addition, the capability to visualize the potential extent of flooding has been shown to motivate residents to take precautions and heed warnings that they previously might have disregarded. In 2019, the USGS, in cooperation with the City of Kansas City, Mo., conducted a project to update a library of flood-inundation maps for a selected reach of the Blue River near Red Bridge Road, Kansas City, Mo.

\section{Purpose and Scope}

This report describes the development of a series of estimated flood-inundation maps for a selected reach of the Blue River near Red Bridge Road, Kansas City, Mo., and identifies where on the internet the maps can be found and ancillary data (geographic information system [GIS] flood polygons and depth grids) can be downloaded. The study extent includes a 4.6-mile reach from 2.52 miles (mi) downstream from the USGS streamgage 06893150, Blue Ridge Boulevard Extension, Kansas City, Mo., to about 0.20 mi upstream from the USGS streamgage 06893500, Blue River at Kansas City, Mo. (see reach 4 in fig. 1). The maps were produced for flood levels referenced to the stage recorded at the USGS streamgage 06893195, Blue River at Red Bridge Road, Kansas City, Mo. (table 1, fig. 1), located within the study reach.

The flood-inundation maps for the reach of the Blue River near Red Bridge Road cover stages ranging from 11.0 to 47.0 feet (ft), referenced to the Blue River at Red Bridge Road, Kansas City, Mo., streamgage local datum. The 11-ft stage approximates the streamflow at the upstream USGS streamgage 06893150, Blue River at Blue Ridge Boulevard Extension that corresponds to the NWS "action stage" or that stage that, when reached by a rising stream, requires the NWS or a partner to take some type of mitigation action in preparation for possible substantial hydrologic activity (NWS, 2019c). The 47-ft stage exceeds the stage corresponding to the estimated 0.2 -percent annual exceedance probability (AEP) flood (500-year recurrence interval flood) at the downstream streamgage 06893500, Blue River at Kansas City, Mo.

\section{Study Area Description}

The Blue River is in west-central Missouri and eastcentral Kansas in the Central Irregular Plains Ecoregion (Omernik, 1987), which can be further divided into the Wooded Osage Plains, Osage Cuestas, Rolling Loess Prairies, and Missouri Alluvial Plain (Omernik, 1987; Nigh and Schroeder, 2002; U.S. Environmental Protection Agency, 2020). The study basin is characterized by gently rolling to moderately hilly topography with about $400 \mathrm{ft}$ of relief.
The headwaters of the Blue River originate in Johnson County, Kansas, and the stream flows generally northward before entering the Kansas City limits. The drainage area at the USGS streamgage 06893195 at Red Bridge Road is 105 square miles ( $\mathrm{mi}^{2}$; table 1$)$. There are no major tributaries within the study reach, but Indian Creek, a major tributary to the Blue River, joins the Blue River immediately downstream from the study reach and within the extent of the hydraulic model. Based on cross-section data from the Blue River hydraulic model (Kellen Huffman, USACE, Kansas City District, written commun., 2012), the Red Bridge Road study reach has an average top-of-bank channel width of about $130 \mathrm{ft}$ and an average channel slope of 8.83 feet per mile.

Based on the 2016 National Land Cover Database (Yang and others, 2018), about 34 percent of the land-cover upstream from the Red Bridge Road study reach was classified as pasture and grassland, 22 percent as low- to high-intensity development, 16 percent as forest, and 12 percent as cropland. In contrast, about 70 percent of the Indian Creek Basin was classified in the low- to high-intensity developed categories in 2016. As of July 2019, there are six structures crossing the Blue River within the study reach: 1 six-lane road, 1 four-lane road, 2 two-lane road, 1 railroad, and 1 pedestrian bridge.

\section{Previous Studies}

Flood-inundation maps for the Blue River previously were developed by Kelly and Rydlund (2006) for the downstream section of the Blue River Basin from streamgage 06893530 at 63 rd Street to the confluence with the Missouri River (reaches 8 through 14, fig. 1, table 1). Flood-inundation maps also were developed by Kelly and Huizinga (2008) for the upstream section of the Blue River Basin from streamgage 06893100 at Kenneth Road, Overland Park, Kans., to streamgage 06893530 at 63rd Street (reaches 3 through 8, fig. 1; table 1). Flood-inundation maps in these studies were generated at 2-ft increments, and all maps were referenced to the streamgage 06893530 at the Blue River at 63rd Street, Kansas City, Mo. Flood-inundation maps for 15 reaches of the Blue River and major tributaries were developed at 1-ft increments by Heimann and others (2014) and referenced to streamgages within each reach. The maps generated in this study supersede those developed for the Blue River reach near Red Bridge Road in the 2014 study (reach 4, fig. 1) as a result of the streamgage at Red Bridge Road being relocated $175 \mathrm{ft}$ downstream to a new bridge in October 2018.

The latest published flood insurance study (FEMA, 2017) presents estimates of the peak streamflows and associated AEPs and their associated water-surface elevations at several locations along the Blue River and selected tributaries. Estimated peak streamflows for AEPs of 10, 2, 1, and 0.2 percent (table 2) at the Blue River at selected locations within the study reach, including the USGS streamgage 06893195, were generated for this study using the USGS StreamStats application (USGS, 2020b) using urban flood-frequency regression equations developed by Southard (2010). 


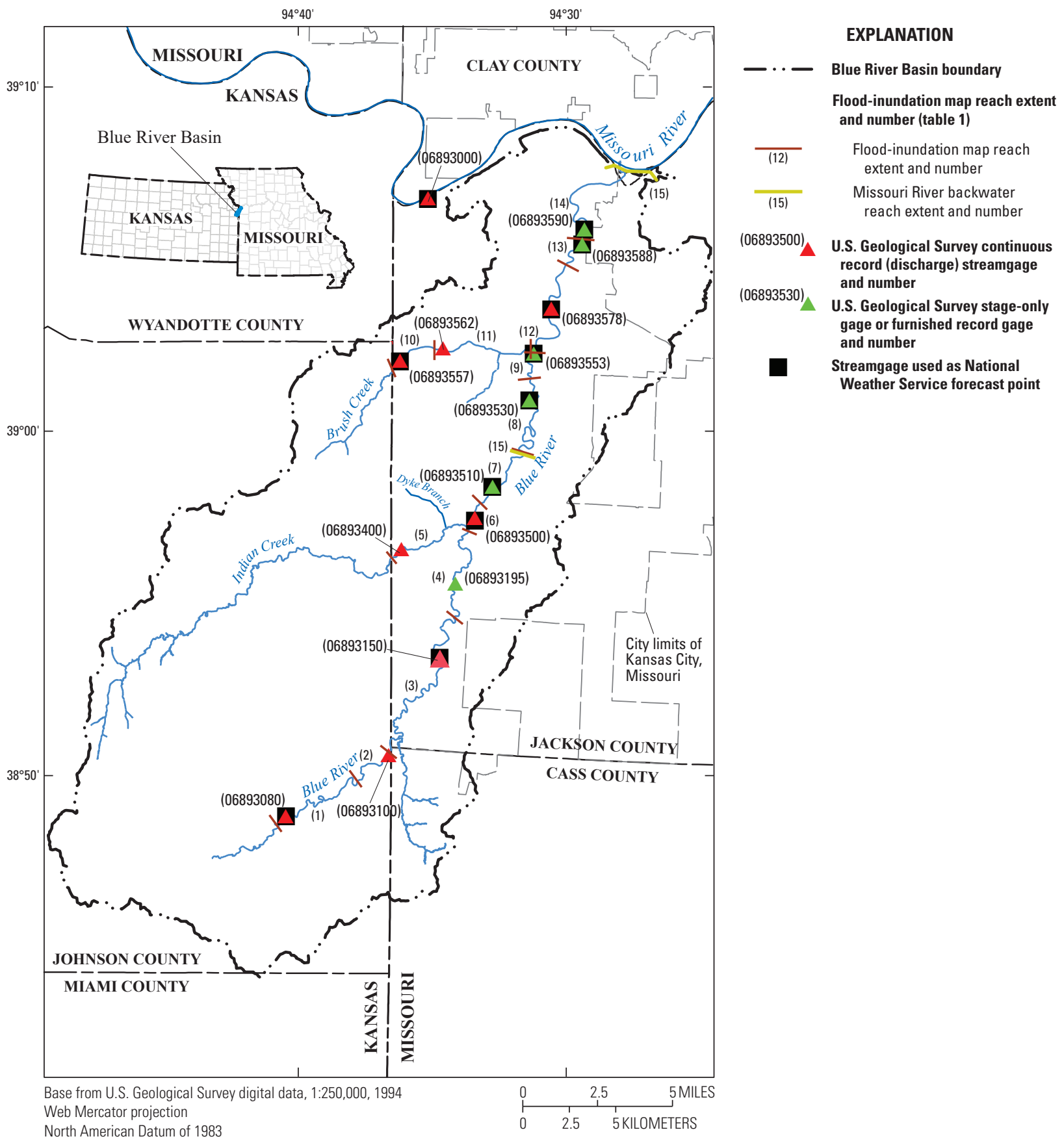

Figure 1. The Blue River Basin, streamgage locations, and extents of the flood-inundation mapping reaches from Heimann and others (2014), including the Blue River near Red Bridge Road map reach (reach 4) updated in this study.

\section{Creation of Flood-Inundation-Map Library}

The USGS has standardized the procedures for creating flood-inundation maps for flood-prone communities (USGS, 2020c) so that the process followed, and products produced, are similar regardless of which USGS office is responsible for the work. Tasks specific to the development of the flood maps for this study included (1) relocating USGS streamgage 06893195, Blue River at Red Bridge Road, Kansas City, Mo. (table 1), (2) surveying bridge cross-sections at selected bridges within the Blue River study reach, (3) calibrating energy-loss factors (roughness coefficients) in the stream channel and floodplain and determining steady-state flow data, (4) computing water-surface profiles using the USACE Hydrologic Engineering Center's River Analysis System (HEC-RAS) computer program (USACE, 2019), 
Table 1. U.S. Geological survey streamgage information for the Blue River Basin, Kansas City, Missouri, and vicinity.

[Latitude and longitude are given in degrees $\left({ }^{\circ}\right)$, minutes $(')$, and seconds $(")$. mi², square mile; ft, foot; NAVD 88, North American Vertical Datum of 1988; ft3/s, cubic foot per second; --, data not available; USGS, U.S. Geological Survey; ALERT, Automated Local Elevation in Real Time]

\begin{tabular}{|c|c|c|c|c|c|c|c|c|c|}
\hline $\begin{array}{l}\text { Reach } \\
\text { number } \\
\text { (fig. 1) }\end{array}$ & Station name & Station type & $\begin{array}{l}\text { Station } \\
\text { number }\end{array}$ & $\begin{array}{c}\text { Drainage } \\
\text { area } \\
\text { (mi2) }\end{array}$ & $\begin{array}{c}\text { Datum } \\
\text { (ft, } \\
\text { NAVD 88) }\end{array}$ & Latitude & Longitude & $\begin{array}{l}\text { Period of record } \\
\text { (water year') }\end{array}$ & $\begin{array}{c}\text { Maximum recorded } \\
\text { stage (ft) and date } \\
\text { (and streamflow } \\
{\left[\mathrm{ft}^{3} / \mathrm{s}\right] \text { ) }}\end{array}$ \\
\hline 1 & $\begin{array}{l}\text { Blue River near } \\
\text { Stanley, Kansas }\end{array}$ & USGS [ALERT] & $\begin{array}{c}06893080 \\
{[2260]}\end{array}$ & 46 & 886.45 & $38^{\circ} 48^{\prime} 45^{\prime \prime}$ & $94^{\circ} 40^{\prime} 32^{\prime \prime}$ & September 1974 to 2020 & $\begin{array}{l}\text { 21.50, August } 22, \\
\text { 2017; }(20,200, \\
\text { May } 15,1990)\end{array}$ \\
\hline 2 & $\begin{array}{l}\text { Blue River at } \\
\text { Kenneth Road, } \\
\text { Overland Park, } \\
\text { Kansas }\end{array}$ & $\begin{array}{l}\text { USGS (stage } \\
\text { only) } \\
\text { [ALERT] }\end{array}$ & $\begin{array}{c}06893100 \\
{[2300]}\end{array}$ & 65.8 & 858.36 & $38^{\circ} 50^{\prime} 32^{\prime \prime}$ & $94^{\circ} 36^{\prime} 44^{\prime \prime}$ & April 2003 to 2020 & $\begin{array}{r}22.29 \text {, August } 22, \\
2017 ;(12,400)\end{array}$ \\
\hline 3 & $\begin{array}{l}\text { Blue River at Blue } \\
\text { Ridge Boulevard } \\
\text { Extension, Kansas } \\
\text { City, Missouri }\end{array}$ & USGS & 06893150 & 93.1 & 800.38 & $38^{\circ} 53^{\prime} 21.9^{\prime \prime}$ & $94^{\circ} 34^{\prime} 50.4^{\prime \prime}$ & June 2002 to 2020 & $\begin{array}{l}\text { 44.50, September 13, } \\
1961 ;(22,600)\end{array}$ \\
\hline 4 & $\begin{array}{l}\text { Blue River at Red } \\
\text { Bridge Road, } \\
\text { Kansas City, } \\
\text { Missouri }\end{array}$ & $\begin{array}{l}\text { USGS (furnished } \\
\text { record }{ }^{1}, \text { stage } \\
\text { only) } \\
\text { [ALERT] }\end{array}$ & $\begin{array}{c}06893195 \\
{[2320]}\end{array}$ & 105 & 774.71 & $38^{\circ} 55^{\prime} 32.5^{\prime \prime}$ & $94^{\circ} 34^{\prime} 17.8^{\prime \prime}$ & October 2018 to 2020 & -- \\
\hline 5 & $\begin{array}{l}\text { Indian Creek at } \\
\text { 103rd Street in } \\
\text { Kansas City, } \\
\text { Missouri }\end{array}$ & USGS & 06893400 & 65 & 722.61 & $38^{\circ} 56^{\prime} 31.1^{\prime \prime}$ & $94^{\circ} 36^{\prime} 16.2^{\prime \prime}$ & $\begin{array}{l}\text { April } 2002 \text { to October } 2008, \\
\text { February } 2011 \text { to } 2020\end{array}$ & $\begin{array}{l}\text { 95.82; July } 30,2008 ; \\
\quad(17,800)\end{array}$ \\
\hline 6 & $\begin{array}{l}\text { Blue River at Kansas } \\
\text { City, Missouri }\end{array}$ & USGS [ALERT] & $\begin{array}{c}06893500 \\
{[2360]}\end{array}$ & 188 & 754.39 & $38^{\circ} 57^{\prime} 25.2^{\prime \prime}$ & $94^{\circ} 33^{\prime} 32.0^{\prime \prime}$ & May 1939 to 2020 & $\begin{array}{l}\text { 44.46, September 13, } \\
\text { 1961; (43,900, } \\
\text { August 22, 2017) }\end{array}$ \\
\hline 7 & $\begin{array}{l}\text { Blue River at } \\
\text { Highway 71, } \\
\text { Kansas City, } \\
\text { Missouri }\end{array}$ & $\begin{array}{l}\text { USGS (furnished } \\
\text { record }{ }^{1} \text {, stage } \\
\text { only) } \\
\text { [ALERT] }\end{array}$ & $\begin{array}{c}06893510 \\
{[2420]}\end{array}$ & 194 & 723.17 & $38^{\circ} 58^{\prime} 19^{\prime \prime}$ & $94^{\circ} 32^{\prime} 52^{\prime \prime}$ & May 2017 to 2020 & $\begin{array}{l}\text { 68.08, August 22, } \\
\text { 2017; -- }\end{array}$ \\
\hline 8 & $\begin{array}{c}\text { Blue River at 63rd } \\
\text { Street, Kansas } \\
\text { City, Missouri }\end{array}$ & $\begin{array}{l}\text { USGS (furnished } \\
\text { record }{ }^{1} \text {, stage } \\
\text { only) } \\
\text { [ALERT] }\end{array}$ & $\begin{array}{c}06893530 \\
{[2440]}\end{array}$ & 204 & 722.41 & $39^{\circ} 00^{\prime} 50^{\prime \prime}$ & $94^{\circ} 31^{\prime} 30^{\prime \prime}$ & -- & $\begin{array}{l}\text { 54.12, May } 15,1990 ; \\
--\end{array}$ \\
\hline 9 & $\begin{array}{l}\text { Blue River at } \\
\text { Colorado Avenue, } \\
\text { Kansas City, } \\
\text { Missouri }\end{array}$ & $\begin{array}{l}\text { USGS (furnished } \\
\text { record }{ }^{1}, \text { stage } \\
\text { only) } \\
\text { [ALERT] }\end{array}$ & $\begin{array}{c}06893553 \\
{[2460]}\end{array}$ & 220 & 699.93 & $39^{\circ} 02^{\prime} 12.4^{\prime \prime}$ & $94^{\circ} 31^{\prime} 21.3^{\prime \prime}$ & -- & $\begin{array}{l}\text { 57.21, August 22, } \\
\text { 2017; -- }\end{array}$ \\
\hline
\end{tabular}


Table 1. U.S. Geological survey streamgage information for the Blue River Basin, Kansas City, Missouri, and vicinity.-Continued

[Latitude and longitude are given in degrees $\left({ }^{\circ}\right)$, minutes ('), and seconds ("). mi², square mile; ft, foot; NAVD 88, North American Vertical Datum of 1988; ft3/s, cubic foot per second; --, data not available; USGS, U.S. Geological Survey; ALERT, Automated Local Elevation in Real Time]

\begin{tabular}{|c|c|c|c|c|c|c|c|c|c|}
\hline $\begin{array}{l}\text { Reach } \\
\text { number } \\
\text { (fig. 1) }\end{array}$ & Station name & Station type & $\begin{array}{l}\text { Station } \\
\text { number }\end{array}$ & $\begin{array}{c}\text { Drainage } \\
\text { area } \\
\left(\mathrm{mi}^{2}\right)\end{array}$ & $\begin{array}{c}\text { Datum } \\
\text { (ft, } \\
\text { NAVD 88) }\end{array}$ & Latitude & Longitude & $\begin{array}{l}\text { Period of record } \\
\text { (water year }{ }^{1} \text { ) }\end{array}$ & $\begin{array}{c}\text { Maximum recorded } \\
\text { stage (ft) and date } 2 \\
\text { (and streamflow } \\
{\left[\mathrm{ft}^{3} / \mathrm{s}\right] \text { ) }}\end{array}$ \\
\hline 10 & $\begin{array}{l}\text { Brush Creek at } \\
\text { Ward Parkway } \\
\text { in Kansas City, } \\
\text { Missouri }\end{array}$ & USGS & 06893557 & 12.2 & 800.48 & $39^{\circ} 01^{\prime} 59.1^{\prime \prime}$ & $94^{\circ} 36^{\prime} 19.4^{\prime \prime}$ & July 1998 to 2020 & $\begin{array}{l}\text { 53.00, September } 12, \\
\text { 1977; }(14,400, \\
\text { July 27, 2017) }\end{array}$ \\
\hline 11 & $\begin{array}{l}\text { Brush Creek at } \\
\text { Rockhill Road } \\
\text { in Kansas City, } \\
\text { Missouri }\end{array}$ & USGS & 06893562 & 17.0 & 800.14 & $39^{\circ} 02^{\prime} 21.3^{\prime \prime}$ & $94^{\circ} 34^{\prime} 43.4^{\prime \prime}$ & July 1998 to 2020 & $\begin{array}{r}\text { 21.71, October 4, } \\
1998 ;(21,700)\end{array}$ \\
\hline 12 & $\begin{array}{l}\text { Blue River at } \\
\text { Stadium Drive } \\
\text { in Kansas City, } \\
\text { Missouri }\end{array}$ & USGS, [ALERT] & $\begin{array}{c}06893578 \\
{[2480]}\end{array}$ & 256 & 718.41 & $39^{\circ} 03^{\prime} 30^{\prime \prime}$ & $94^{\circ} 30^{\prime} 42^{\prime \prime}$ & July 2002 to 2020 & $\begin{array}{l}\text { 46.96, May } 15,1990 ; \\
\quad(33,400)\end{array}$ \\
\hline 13 & $\begin{array}{c}\text { Blue River at } 17 \text { th } \\
\text { Street, Kansas } \\
\text { City, Missouri }\end{array}$ & $\begin{array}{l}\text { USGS (furnished } \\
\text { record }^{3} \text {, stage } \\
\text { only) } \\
\text { [ALERT] }\end{array}$ & $\begin{array}{c}06893588 \\
{[2500]}\end{array}$ & 256 & 722.38 & $39^{\circ} 05^{\prime} 22^{\prime \prime}$ & $94^{\circ} 29^{\prime} 32^{\prime \prime}$ & -- & -- \\
\hline 14 & $\begin{array}{c}\text { Blue River at 12th } \\
\text { Street in Kansas } \\
\text { City, Missouri }\end{array}$ & $\begin{array}{l}\text { USGS (stage } \\
\text { only) }\end{array}$ & 06893590 & 258 & 714.84 & $39^{\circ} 05^{\prime} 48.9^{\prime \prime}$ & $94^{\circ} 29^{\prime} 27.7^{\prime \prime}$ & $\begin{array}{l}\text { October } 1982 \text { to } \\
\text { September } 1984 \text {, } \\
\text { October } 1987 \text { to } \\
\text { November } 1993 \text {, } \\
\text { October } 1994 \text { to } \\
\text { September } 1996 \text {, } \\
\text { October } 1998 \text { to } \\
\text { September } 2002 \text {, } \\
\text { October } 2006 \text { to } 2020\end{array}$ & $\begin{array}{l}\text { 38.00, September } 13 \text {, } \\
\text { 1977; }(34,900, \\
\text { September 13, } \\
\text { 1977) }\end{array}$ \\
\hline 15 & $\begin{array}{l}\text { Missouri River at } \\
\text { Kansas City, } \\
\text { Missouri }\end{array}$ & USGS & 06893000 & 484,100 & 706.68 & $39^{\circ} 06^{\prime} 42.2^{\prime \prime}$ & $94^{\circ} 35^{\prime} 17.3^{\prime \prime}$ & October 1928 to 2020 & $\begin{array}{l}\text { 48.87, July } 27,1993 ; \\
\text { (625,000, June } 16 \\
1844)\end{array}$ \\
\hline
\end{tabular}

${ }^{1} \mathrm{~A}$ water year is the 12 -month period from October 1 through September 30 of the following year and is designated by the calendar year in which it ends.

2Unless otherwise specified, the date of the maximum recorded streamflow corresponds to that of the maximum recorded stage.

3Furnished record is collected by City of Kansas City, Missouri, at ALERT gages and is accepted and furnished through the U.S. Geological Survey National Water Information System (U.S. Geological Survey, 2020d). 
Table 2. Peak streamflows for selected annual exceedance probabilities for the Blue River at Kansas City, Missouri.

[Data from U.S. Geological Survey (2020b). $\mathrm{mi}^{2}$, square mile; $\mathrm{ft}^{\mathrm{3}} / \mathrm{s}$, cubic foot per second; USGS, U.S. Geological Survey]

\begin{tabular}{rccccc}
\hline & $\begin{array}{c}\text { Drainage } \\
\text { area }\end{array}$ & \multicolumn{4}{c}{$\begin{array}{c}\text { Estimated streamflows }(\mathbf{f t} \text { / } / \mathbf{s}) \text { for indicated annual } \\
\text { exceedance probability (percent) }\end{array}$} \\
\cline { 3 - 6 } & $\left(\mathbf{m i}^{2}\right)$ & $\mathbf{1 0}$ & $\mathbf{2}$ & $\mathbf{1}$ & $\mathbf{0 . 2}$ \\
\hline At USGS streamgage 06893150 & 93.1 & 8,250 & 14,300 & 17,200 & 25,600 \\
At USGS streamgage 06893195 & 105 & 9,020 & 15,600 & 18,700 & 27,800 \\
At USGS streamgage 06893500 & 188 & 15,900 & 26,500 & 31,200 & 45,400 \\
\hline
\end{tabular}

(5) producing estimated flood-inundation maps for selected stream stages using HEC-RAS and a GIS, and (6) preparing the maps as shapefile polygons that depict the areal extent of flood inundation at various stages, and as depth grids that provide the depth of floodwaters for display on a USGS floodinundation mapping application.

\section{Computation of Water-Surface Profiles}

The hydraulic model used in this study was developed in 2010 by the USACE and is the same model used in the previous flood-inundation mapping study for the Blue River and tributaries (Heimann and others, 2014). This model, which was developed using HEC-RAS version 5.0.7 (USACE, 2019), was calibrated by the USGS and used to produce the flood-inundation maps in this study. HEC-RAS is a onedimensional model for simulation of water-surface profiles with steady-state (gradually varied) or unsteady-state flow computation options.

\section{Hydrologic Data}

The study reach includes one USGS streamgage (06893195; fig. 1; table 1) with a record furnished by the City of Kansas City ALERT gage at this location. Stage is measured and transmitted at a minimum of every 4 hours (every 15 minutes during rapidly changing stage conditions) and made available on the internet through the USGS National Water Information System (USGS, 2020d) and StormWatch (https://www.stormwatch.com/). Stage data from this streamgage are referenced to a local datum but can be converted to water-surface elevations referenced to the North American Vertical Datum of 1988 (NAVD 88) by adding $774.71 \mathrm{ft}$.

The estimated streamflows used for specific stages in the model simulations (table 3 ) were obtained from a theoretical stage-streamflow rating (Turnipseed and Sauer, 2010) for the streamgage locations that were derived from the calibrated hydraulic model using a range of simulated peak streamflows (table 2). No major tributaries join the Blue River within the 4.6-mile study reach; however, a major tributary, Indian Creek, joins the Blue River just downstream from the study reach and within the simulation reach. The streamflows at a flow-change location 0.2 mi downstream from the end of the Red Bridge Road study reach (mile 20.304 in model) were adjusted for Indian Creek inflows (table 3). The urban regression floodfrequency equations developed by Southard (2010) indicate the substantial effect of impervious area and drainage area on peak streamflows. Although the drainage area of Indian Creek (74 $\mathrm{mi}^{2}$ at the confluence with the Blue River) is less than that of the Blue River (109 $\mathrm{mi}^{2}$ at confluence), the impervious area within the Indian Creek Basin (31.2 percent) as estimated by the USGS StreamStats application (USGS, 2020b), is substantially greater than that of the upper Blue River Basin (7.5 percent). Flow adjustments for the Indian Creek tributary, therefore, were estimated based on the ratio of peak flows for the range of probability estimates generated from the USGS StreamStats application, rather than on drainage area alone. This allows the flow estimates at the flow-change location to reflect differences in drainage area and impervious area for the two basins. The flood-inundation maps generated for this study, therefore, are based on the assumption that conditions generating runoff in the Indian Creek Basin are comparable to those of the upper Blue River Basin.

\section{Topographic and Bathymetric Data}

All topographic data used in this study are referenced vertically to NAVD 88 and horizontally to the North American Datum of 1983. The elevation data for cross sections were obtained from a digital elevation model (DEM) that was derived from light detection and ranging (lidar) data that were collected during March 2018 by Kucera International and obtained from the City of Kansas City (James Walton, written commun., Kansas City Water Services, 2019). The postprocessing of these data was completed by Kucera International in September 2018. The DEM, covering the city limits of Kansas City and selected surrounding areas, was provided by the City of Kansas City (James Walton, Kansas City Water Services Department, written commun., 2019). As per USGS version 1.2, quality level 2 data-accuracy specifications (Heidemann, 2018), the lidar data required a nonvegetated vertical accuracy of a maximum 10-centimeter root mean square error, and a vegetated vertical accuracy of a maximum 30 centimeters at the 95 th percentile. The accuracy specifications meet or exceeded the National Map Accuracy standards for 
Table 3. Estimated streamflows for corresponding stages and water-surface elevations at selected locations, used in the hydraulic model of the Blue River at Kansas City, Missouri.

[ft, foot; NAVD 88, North American Vertical Datum of 1988; ft3/s, cubic foot per second]

\begin{tabular}{|c|c|c|c|}
\hline \multirow{2}{*}{$\begin{array}{c}\text { Stage of water-surface } \\
\text { profile } \\
\text { (ft) }\end{array}$} & \multirow{2}{*}{$\begin{array}{l}\text { Water-surface elevation } \\
\text { (ft, NAVD 88) }\end{array}$} & \multicolumn{2}{|c|}{ Estimated streamflow at indicated location (ft3/s) } \\
\hline & & $\begin{array}{l}\text { At upstream end of study reach } \\
\text { at river mile 27.54 }\end{array}$ & $\begin{array}{l}\text { At model flow-change location } \\
\text { at river mile } 20.304\end{array}$ \\
\hline 11 & 785.71 & 2,200 & 6,400 \\
\hline 12 & 786.71 & 2,550 & 7,250 \\
\hline 13 & 787.71 & 3000 & 8,340 \\
\hline 14 & 788.71 & 3,400 & 9,300 \\
\hline 15 & 789.71 & 3,900 & 10,400 \\
\hline 16 & 790.71 & 4,500 & 11,800 \\
\hline 17 & 791.71 & 5,100 & 13,200 \\
\hline 18 & 792.71 & 5,800 & 14,700 \\
\hline 19 & 793.71 & 6,450 & 16,100 \\
\hline 20 & 794.71 & 7,250 & 17,800 \\
\hline 21 & 795.71 & 7,900 & 19,200 \\
\hline 22 & 796.71 & 8,700 & 20,900 \\
\hline 23 & 797.71 & 9,500 & 22,600 \\
\hline 24 & 798.71 & 10,200 & 24,000 \\
\hline 25 & 799.71 & 11,100 & 25,800 \\
\hline 26 & 800.71 & 12,400 & 28,500 \\
\hline 27 & 801.71 & 13,800 & 31,300 \\
\hline 28 & 802.71 & 15,000 & 33,600 \\
\hline 29 & 803.71 & 16,000 & 35,600 \\
\hline 30 & 804.71 & 17,100 & 37,700 \\
\hline 31 & 805.71 & 18,300 & 40,800 \\
\hline 32 & 806.71 & 19,700 & 42,700 \\
\hline 33 & 807.71 & 21,000 & 45,200 \\
\hline 34 & 808.71 & 22,400 & 47,800 \\
\hline 35 & 809.71 & 23,800 & 50,400 \\
\hline 36 & 810.71 & 25,100 & 52,900 \\
\hline 37 & 811.71 & 27,000 & 56,400 \\
\hline 38 & 812.71 & 28,800 & 59,700 \\
\hline 39 & 813.71 & 30,500 & 62,800 \\
\hline 40 & 814.71 & 32,500 & 66,500 \\
\hline 41 & 815.71 & 34,600 & 70,200 \\
\hline 42 & 816.71 & 36,800 & 74,200 \\
\hline 43 & 817.71 & 39,000 & 78,000 \\
\hline 44 & 818.71 & 41,500 & 83,000 \\
\hline 45 & 819.71 & 43,400 & 86,800 \\
\hline 46 & 820.71 & 46,800 & 93,600 \\
\hline 47 & 821.71 & 50,200 & 100,400 \\
\hline
\end{tabular}

1 Water-surface profiles are 1-foot increments of stage, referenced to the gage datum of the U.S. Geological Survey streamgage 06893195, Blue River at Red Bridge Road, Kansas City, Missouri. 
vertical and horizontal accuracy guidelines for 2-ft contours (American Society for Photogrammetry and Remote Sensing, 1990, 2004).

Because lidar data cannot provide ground elevations below a stream's water surface, channel cross sections were surveyed by USGS field crews during July 2019. The ground surface along cross sections was measured by taping down from reference elevations along the bridge decks. A differential global positioning system with real-time kinematic technology was used to derive reference elevations for the bridge decks from which channel bed elevations were derived.

\section{Hydraulic Structures}

Six bridges are represented in the Red Bridge Road reach hydraulic model and have the potential to affect water-surface elevations during flooding along the stream. These six bridges are 1 major six-lane highway bridge, 1 four-lane road bridge, 2 two-lane road bridges, 1 railroad bridge, and 1 pedestrian trail bridge. Initial bridge-geometry data were obtained from a HEC-RAS (USACE, 2019) model developed by the USACE as described in Heimann and others (2014) and updated and verified through field surveys by personnel from the USGS.

\section{Energy-Loss Factors}

Hydraulic analyses require estimating energy losses that result from frictional resistance exerted by a channel on flow. These energy losses are quantified by the Manning's roughness coefficient (" $n$ " value). Initial (precalibration) $n$ values were selected on the basis of field observations, high-resolution aerial photographs collected through the U.S. Department of Agriculture, National Agriculture Imagery Program and available through the Missouri Spatial Data Information Service (2019), and tabulated estimates of $n$ values (Chow, 1959).

As part of the calibration process, the initial $n$ values were varied by flow and adjusted until the differences between simulated and observed water-surface elevations at the streamgage and elsewhere along the study reach were minimized. The final $n$ values ranged from 0.045 to 0.055 for the main channel and from 0.07 to 0.15 for the overbank areas simulated in this analysis. The lowest channel coefficients were placed in straight, upstream sections of the model reach, and the highest were placed in sinuous, low-gradient, fine-material substrate reaches with vegetated banks in the downstream sections of the study reach. The lowest roughness coefficients on the floodplain were placed in open recreation fields, and the highest were placed in densely forested areas.

\section{Hydraulic Model}

The hydraulic analysis for this study was done by using the steady-state flow computation option in HEC-RAS (USACE, 2019). Steady-state flow data consisted of flow regime, boundary conditions, and peak flows that produced water-surface elevations at the streamgage cross section that matched target water-surface elevations. These target elevations coincided with 1-ft increments of stage, referenced to the local gage datum. Subcritical (tranquil) flow regime was assumed for the simulations. Normal depth, based on an estimated average water-surface slope of 0.00036 , was used as the reach's downstream boundary condition. The peak flows used in the model were discussed in the "Hydrologic Data" section.

The HEC-RAS model was calibrated to stage-streamflow relations developed at USGS streamgages at the upstream (rating number 7.0 at streamgage 06893150 , Blue River at Blue Ridge Boulevard Extension, Kansas City, Mo.), and downstream (rating number 34.0 at streamgage 06893500, Blue River at Kansas City, Mo.) boundaries of the model reach (tables 4,5). The flow conditions of stages at and above the NWS "action stage" were used in the calibration at each streamgage. Model calibration was accomplished by adjusting Manning's $n$ values until the results of the hydraulic computations closely agreed with the observed water-surface elevations for given flows. Differences between target and simulated water-surface elevations for selected flows at the USGS streamgages were equal to or less than $0.57 \mathrm{ft}$ (tables 4, 5). The results demonstrate that the model is capable of simulating accurate water levels throughout the reach over a large range of stages and flows.

\section{Development of Water-Surface Profiles}

The calibrated hydraulic model was used to generate water-surface profiles for 37 stages at 1-ft intervals from 11.0 to $47.0 \mathrm{ft}$ as referenced to the local datum of the USGS streamgage 06893195, Blue River at Red Bridge Road, Kansas City, Mo. These stages correspond to elevations of 785.71 and $821.71 \mathrm{ft}$, NAVD 88, respectively (table 3). Streamflows corresponding to the various stages were obtained from the theoretical rating generated by the calibrated HEC-RAS model for the Blue River at Red Bridge Road, Kansas City, Mo. Watersurface profiles in the mapped reach could be affected by contributed flows from Indian Creek immediately downstream from the mapped reach; therefore, a flow-change location (fig. 1; table 3) was included in the model downstream from the Indian Creek confluence.

\section{Development of Flood-Inundation Maps}

Flood-inundation maps were created for the Blue River near Red Bridge Road study reach and referenced to USGS streamgage 06893195, Blue River at Red Bridge Road, Kansas City, Mo. The DEM data were derived from the same lidar data described previously in the "Topographic and Bathymetric Data" section and therefore have an estimated vertical accuracy of $2 \mathrm{ft}$ (that is, plus or minus $1 \mathrm{ft}$ ). Estimated flood-inundation boundaries for each simulated profile were developed with HEC-RAS mapper and exported from 
Table 4. Calibration of model to target water-surface elevations at U.S. Geological Survey streamgage 06893150, Blue River at Blue Ridge Boulevard Extension, Kansas City, Missouri.

[ft, foot; NAVD 88, North American Vertical Datum of 1988]

\begin{tabular}{cccc}
\hline $\begin{array}{c}\text { Stage of water-surface profile } 1 \\
\text { (ft) }\end{array}$ & $\begin{array}{c}\text { Target water-surface elevation } \\
\text { (ft, NAVD 88) }\end{array}$ & $\begin{array}{c}\text { Simulated water-surface } \\
\text { elevation } \\
\text { (ft, NAVD 88) }\end{array}$ & $\begin{array}{c}\text { Difference in elevation } \\
\text { (ft) }\end{array}$ \\
\hline 29.68 & 830.00 & 829.92 & -0.08 \\
30.68 & 831.00 & 831.21 & 0.21 \\
31.68 & 832.00 & 832.43 & 0.43 \\
32.68 & 833.00 & 833.38 & 0.38 \\
33.68 & 834.00 & 834.33 & 0.33 \\
34.68 & 835.00 & 835.21 & 0.21 \\
35.68 & 836.00 & 836.03 & 0.03 \\
36.68 & 837.00 & 836.82 & -0.18 \\
37.68 & 838.00 & 837.61 & -0.39 \\
38.68 & 839.00 & 839.17 & 0.17 \\
41.68 & 840.00 & 840.13 & 0.13 \\
\end{tabular}

${ }^{1}$ Water-surface profiles are 1-foot increments of stage, referenced to the gage datum of the U.S. Geological Survey streamgage 06893150, Blue River at Blue Ridge Boulevard Extension, Kansas City, Missouri.

Table 5. Calibration of model to target water-surface elevations at U.S. Geological Survey streamgage 06893500, Blue River at Kansas City, Missouri.

[ft, foot; NAVD 88, North American Vertical Datum of 1988]

\begin{tabular}{cccc}
\hline $\begin{array}{c}\text { Stage of water-surface profile) } \\
\text { (ft) }\end{array}$ & $\begin{array}{c}\text { Target water-surface elevation } \\
\text { (ft, NAVD 88) }\end{array}$ & $\begin{array}{c}\text { Simulated water-surface } \\
\text { elevation } \\
\text { (ft, NAVD 88) }\end{array}$ & $\begin{array}{c}\text { Difference in elevation } \\
\text { (ft) }\end{array}$ \\
\hline 27.96 & 782.00 & 782.57 & 0.57 \\
28.96 & 783.00 & 783.30 & 0.30 \\
29.96 & 784.00 & 784.02 & 0.02 \\
30.96 & 785.00 & 784.74 & -0.26 \\
31.96 & 786.00 & 785.60 & -0.40 \\
32.96 & 787.00 & 786.77 & -0.23 \\
33.96 & 788.00 & 787.93 & -0.07 \\
34.96 & 789.00 & 789.08 & 0.09 \\
35.96 & 790.00 & 790.29 & 0.29 \\
36.96 & 791.00 & 791.39 & 0.39 \\
37.96 & 792.00 & 791.55 & -0.44 \\
38.96 & 793.00 & 792.52 & -0.48 \\
39.96 & 794.00 & 793.78 & -0.21 \\
40.96 & 795.00 & 795.02 & 0.02 \\
41.96 & 796.00 & 796.08 & 0.08 \\
\hline
\end{tabular}

${ }^{1}$ Water-surface profiles are 1-foot increments of stage, referenced to the gage datum of the U.S. Geological Survey streamgage 06893500, Blue River at Kansas City, Missouri. 
HEC-RAS (USACE, 2019). Shapefile polygons and depth grids of the inundated areas for each profile were modified, as required, in the ArcMap application of ArcGIS (Esri, 2020) to ensure a hydraulically reasonable transition of the flood boundaries between simulation cross sections.

Any inundated areas that were detached from the main channel were examined to identify subsurface connections with the main river, such as through culverts under roadways. Where such connections existed, the mapped inundated areas were retained in their respective flood maps; otherwise, the erroneously delineated parts of the flood extent were deleted. The flood-inundation areas are overlaid on high-resolution, georeferenced, aerial photographs of the study area. Bridge surfaces are shown as not inundated until the lowest flood stage that either exceeds the bridge deck or completely inundates both approaches to the bridge. In these latter circumstances, the bridge surface is depicted as being inundated. Estimates of water depth can be obtained from the depth-grid data (Heimann and others, 2020) that are included with the presentation of the flood maps on an interactive USGS mapping application described in the following section, "FloodInundation Map Delivery." The flood map corresponding to the highest simulated water-surface profile, a stage of $47.0 \mathrm{ft}$, is presented in figure 2 .

\section{Flood-Inundation Map Delivery}

The current study documentation is available online at the USGS Publications Warehouse https://doi.org/10.3133/ sir20205057). Also, a Flood Inundation Mapping Program website (https://www.usgs.gov/mission-areas/water-resources/ science/flood-inundation-mapping-fim-program?qt-science center_objects $=0 \# q t-s c i e n c e$ center_objects; USGS, 2020c) has been established to make USGS flood-inundation study information available to the public. The website links to a mapping application that presents map libraries and provides detailed information on flood extents and depths for the simulations. The mapping application enables the production of customized flood-inundation maps from the map library for the Blue River near Red Bridge Road, Kansas City, Mo. (Heimann and others, 2020). A link on the mapping application website connects to the USGS National Water Information System (USGS, 2020d), which presents the current stage at USGS streamgage 06893195, Blue River at Red Bridge Road, Kansas City, Mo., to which the inundation maps are referenced. Additionally, a link is provided on the mapping application to the USGS WaterAlert application (USGS, 2020e), which notifies the user when a specified stage threshold is reached. The estimated flood-inundation maps are displayed in sufficient detail so that preparations for flooding and decisions for emergency response can be performed efficiently. Depending on the flood magnitude, roadways are shown as shaded (inundated and likely impassable) or not shaded (dry and passable) to facilitate emergency planning and use. Bridges are shaded - that is, shown as inundated - when the flood stage exceeds the elevation of the bridge deck. A shaded building should not be interpreted to mean that the structure is completely submerged but, rather, that bare earth surfaces near the building are inundated. In these instances, the water depth (as indicated in the mapping application by holding the cursor over an inundated area) near the building would be an estimate of the water level inside the structure, unless flood-proofing measures had been implemented.

\section{Disclaimer for Flood-Inundation Maps}

The flood-inundation maps should not be used for navigation, regulatory, permitting, or other legal purposes. The USGS provides these maps "as-is" for a quick reference, emergency planning tool but assumes no legal liability or responsibility resulting from the use of this information.

\section{Uncertainties and Limitations Regarding Use of Flood-Inundation Maps}

Although the flood-inundation maps represent the boundaries of inundated areas with a distinct line, some uncertainty is associated with these maps. The flood boundaries shown were estimated on the basis of water stages and streamflows at selected USGS streamgages. Water-surface elevations along the stream reaches were estimated by steady-state hydraulic modeling, assuming unobstructed flow, and used streamflows and hydrologic conditions anticipated at the USGS streamgage(s). The hydraulic model reflects the land-cover characteristics and any bridge, dam, levee, or other hydraulic structures existing as of July 2019. Unique meteorological factors (timing and distribution of precipitation) may cause actual streamflows along the simulation reach to vary from those assumed during a flood, which may lead to deviations in the water-surface elevations and inundation boundaries shown. Additional areas may be flooded due to unanticipated conditions such as changes in the streambed elevation or roughness, backwater into major tributaries along a main stem river, or backwater from localized debris or ice jams. The accuracy of the floodwater extent portrayed on these maps will vary with the accuracy of the digital elevation model used to simulate the land surface. 


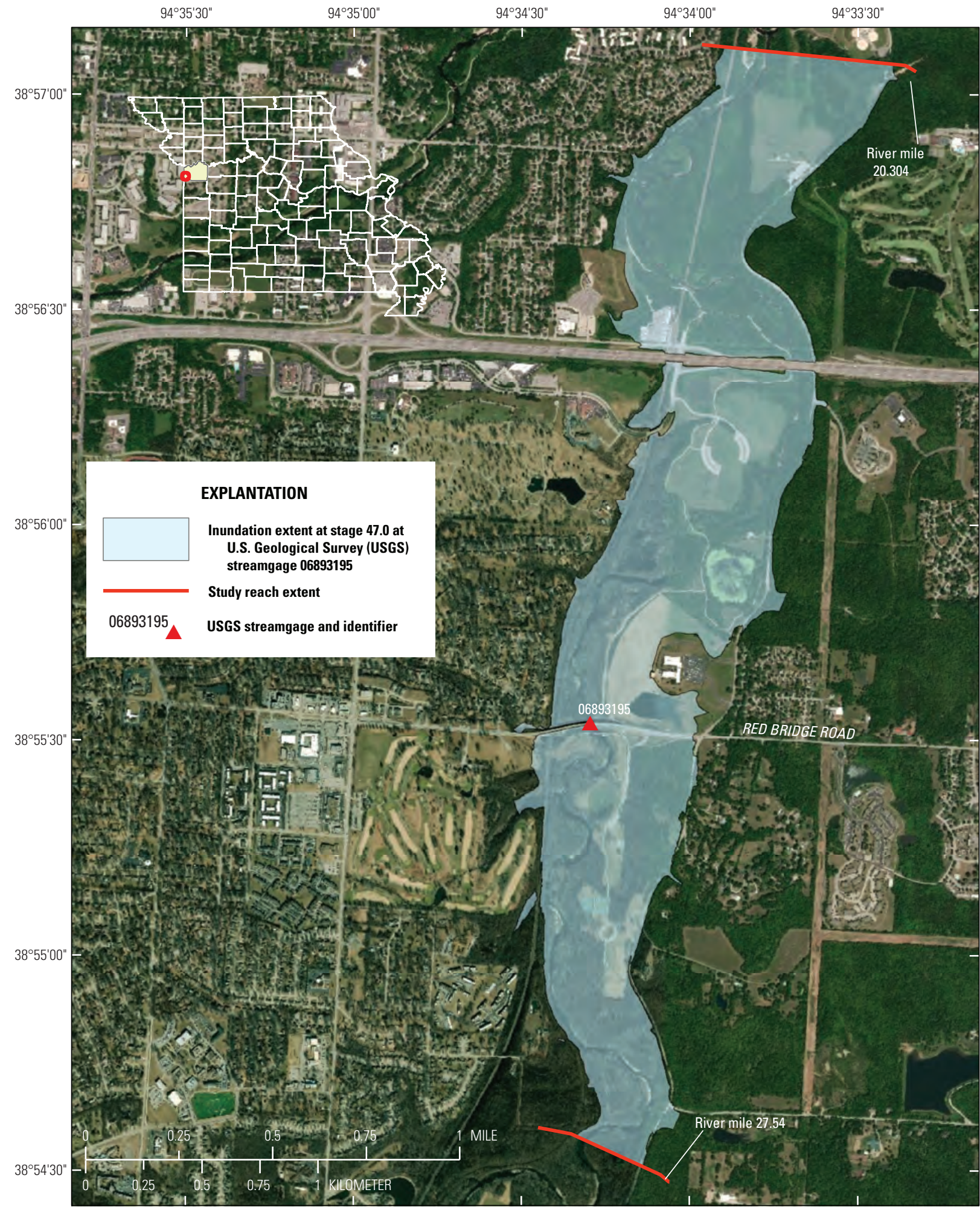

Map image is the intellectual property of Esri and is used herein under license.

Copyright (C) 2019 Esri and its licensors. All rights reserved

World Geodetic System 1984 Web Mercator (Auxillary Sphere) projections

Horizontal coordinate information referenced to the North American Datum of 1983 (NAD 83)

Figure 2. Flood-inundation map for the Blue River near Red Bridge Road study reach in Kansas City, Missouri, corresponding to a stage of 47.0 feet at the U.S. Geological Survey streamgage 06893195 at Red Bridge Road. 


\section{Summary}

A series of 37 digital flood-inundation maps were developed in cooperation with the City of Kansas City, Missouri, for the Blue River in Kansas City, Mo. The maps cover a reach about 4.6 miles long within the city limits. The maps were developed by using the U.S. Army Corps of Engineers' Hydrologic Engineering Center's River Analysis System (HEC-RAS) computer program to compute water-surface profiles and to delineate estimated flood-inundation areas and depths of flooding for selected stream stages. The HECRAS hydraulic model was calibrated to discrete streamflow measurements from the U.S. Geological Survey (USGS) streamgages at the upstream (06893150, Blue River at Blue Ridge Boulevard Extension, Kansas City, Mo.) and downstream (06893500, Blue River at Kansas City, Mo.) extents of the simulation reach. The model encompassing the Red Bridge Road study reach was used to compute 37 water-surface profiles for flood stages at 1 -foot (ft) intervals referenced to the local streamgage datum and ranging from $11.0 \mathrm{ft}$, or near bankfull, to $47.0 \mathrm{ft}$, which exceeds the stage corresponding to the estimated 0.2 percent annual exceedance probability flood (500-year recurrence interval).

The simulated water-surface profiles were then combined with a geographic information system digital elevation model derived from light detection and ranging data to delineate estimated flood-inundation areas as shapefile polygons and depth grids for each profile. These flood-inundation polygons were overlaid on high-resolution, georeferenced aerial photographs of the study area. The flood maps are available through a mapping application that can be accessed on the USGS Flood Inundation Mapping Program website (https://www.usgs.gov/mission-areas/water-resources/science/ flood-inundation-mapping-fim-program).

Interactive use of the maps on this mapping application can give users a general indication of depth of water at any point by using the mouse cursor to click within the shaded areas. These maps are used in conjunction with the real-time stage data from the USGS reference streamgage 06893195 , Blue River at Red Bridge Road, Kansas City, Mo. The joint products can help guide the general public in taking individual safety precautions and provides emergency-management personnel with a tool to mitigate and prepare for flood-related emergencies, efficiently manage emergency flood operations, and effectively conduct postflood recovery efforts.

\section{References Cited}

American Society for Photogrammetry and Remote Sensing, 1990, ASPRS accuracy standards for largescale maps: American Society for Photogrammetry and Remote Sensing, accessed December 17, 2018, at http://www.asprs.org/a/society/committees/standards/1990_ jul_1068-1070.pdf.

American Society for Photogrammetry and Remote Sensing, 2004, ASPRS guidelines-Vertical accuracy reporting for lidar data: American Society for Photogrammetry and Remote Sensing, accessed December 17, 2018, at https://www.asprs.org/a/society/committees/standards/ Vertical_Accuracy_Reporting_for_Lidar_Data.pdf.

Chow, V.T., 1959, Open-channel hydraulics: New York, McGraw-Hill, 680 p.

Esri, 2020, ArcGIS (ver. 10.7.1): Esri software, accessed January 12, 2020, at https://www.esri.com/software/arcgis/.

Federal Emergency Management Agency [FEMA], 2017, Flood insurance study-Jackson County, Missouri and incorporated areas and Kansas City: Federal Emergency Management Agency, v. 1, accessed October 2, 2019, at https://map1.msc.fema.gov/data/29/S/PDF/29095CV001B.pdf? LOC $=3 b 8040 a 98 c 0 a 56 d d 89 a 20 d 3 b c 7 c b 5 a 10$.

Hauth, L.D., Carswell, W.J., Jr., and Chin, E.H., 1981, Floods in Kansas City, Missouri and Kansas, September 12-13, 1977: U.S. Geological Survey Professional Paper 1169, 47 p., accessed February 4, 2020 at https://doi.org/10.3133/ pp11699.

Heidemann, H.K., 2018, Lidar base specification (ver. 1.3, February 2018): U.S. Geological Survey Techniques and Methods, book 11, chap. B4, 101 p., accessed February 7, 2020, at https://doi.org/10.3133/tm11b4.

Heimann, D.C., Voss, J.D., and Rydlund, P.H., Jr., 2020, Geospatial datasets for the flood-inundation study of the Blue River near Red Bridge Road, Kansas City, Missouri, 2019: U.S. Geological Survey data release, https://doi.org/ 10.5066/P90MH291. 
Heimann, D.C., Weilert, T.E., Kelly, B.P., and Studley, S.E., 2014, Flood-inundation maps and Wetland Restoration Suitability Index for the Blue River and selected tributaries, Kansas City, Missouri, and vicinity, 2012: U.S. Geological Survey Scientific Investigations Report 2014-5180, 23 p., accessed January 3, 2020, at https://doi.org/10.3133/ sir20145180.

Kelly, B.P., and Huizinga, R.J., 2008, Estimated floodinundation mapping for the Upper Blue River, Indian Creek, and Dyke Branch in Kansas City, Missouri, 2006-08: U.S. Geological Survey Scientific Investigations Report 2008-5068, 34 p., plus appendixes, accessed January 3, 2020, at https://pubs.usgs.gov/sir/2008/5068/.

Kelly, B.P., and Rydlund, P.H., Jr., 2006, Estimated floodinundation mapping for the lower Blue River in Kansas City, Missouri, 2003-05: U.S. Geological Survey Scientific Investigations Report 2006-5089, 27 p., accessed January 3, 2020, at https://pubs.usgs.gov/sir/2006/5089/pdf/report.pdf.

Missouri Spatial Data Information Service, 2019, Missouri imagery data: Missouri Spatial Data Information Service digital data, accessed September 14, 2019, at http://www.msdis.missouri.edu/data/imagery/index.html. [NAIP 2018 data directly accessible at http://msdisarchive.missouri.edu/archive/Missouri_Imagery/naip2018/.]

National Weather Service [NWS], 2019a, Advanced Hydrologic Prediction Service river forecasts - Blue River at Bannister Road: National Weather Service digital data, accessed March 26, 2020, at https://water.weather.gov/ ahps $2 /$ hydrograph.php? $\mathrm{wfo}=$ eax \&gage $=\mathrm{kccm} 7 \&$ prob_type $=$ stage\&source $=$ hydrograph.

National Weather Service [NWS], 2019b, Event summariesKansas City/Pleasant Hill, MO: National Weather Service web page, accessed November 17, 2019, at https://www.weather.gov/eax/events.

National Weather Service [NWS], 2019c, National Weather Service glossary-Action stage: National Weather Service web page, accessed November 17, 2019, at https://w1.weather.gov/glossary/index.php?word= action+stage.

Nigh, T.A., and Schroeder, W.A., 2002, Atlas of Missouri ecoregions. Missouri Department of Conservation, $212 \mathrm{p}$.

Omernik, J.M., 1987, Ecoregions of the conterminous United States: Association of American Geographers, v. 77, no. 1, p. 118-125. [Also available at https://doi.org/10.1111/ j.1467-8306.1987.tb00149.x.].

Southard, R.E., 2010, Estimation of the magnitude and frequency of floods in urban basins in Missouri: U.S. Geological Survey Scientific Investigations Report 2010-5073, 27 p., accessed January 18, 2020, at https://doi.org/10.3133/sir20105073.
Turnipseed, D.P., and Sauer, V.B., 2010, Discharge measurements at gaging stations: U.S. Geological Survey Techniques and Methods, book 3, chap. A8, 87 p. [Also available at https://doi.org/10.3133/tm3A8.]

U.S. Army Corps of Engineers [USACE], 1967, Flood plain information-Blue River within Kansas City: Missouri, U.S. Army Corps of Engineers, Kansas City District, $31 \mathrm{p}$.

U.S. Army Corps of Engineers [USACE], 2019, HECRAS - River analysis system-Hydraulic reference manual (ver. 5.0.7, March 2019): U.S. Army Corps of Engineers, [variously paged], accessed May 15, 2019, at https:/www.hec.usace.army.mil/software/hec-ras/ download.aspx.

U.S. Census Bureau, 2020, QuickFacts-United States population estimates: U.S. Census Bureau, accessed January 18, 2020, at https://www.census.gov/quickfacts/fact/table/US/ PST045219.

U.S. Environmental Protection Agency, 2020, Ecoregion download files by State-Region 7-Level IV Ecoregions of Iowa and Missouri: U.S. Environmental Protection Agency digital data, accessed January 14, 2020, at https://www.epa.gov/eco-research/ecoregion-downloadfiles-state-region-7.

U.S. Geological Survey [USGS], 2020a, USGS 06893195 Blue River at Red Bridge Road, Kansas City, Mo, in USGS water data for the Nation: U.S. Geological Survey National Water Information System database, accessed January 4, 2020, at https://doi.org/10.5066/F7P55KJN. [Site information directly accessible at https://waterdata.usgs.gov/nwis/ uv?site_no=06893195.]

U.S. Geological Survey [USGS], 2020b, StreamStats: U.S. Geological Survey web-based application, accessed January 8, 2020, at https://streamstats.usgs.gov/ss/.

U.S. Geological Survey [USGS], 2020c, Flood Inundation Mapping (FIM) Program: U.S. Geological Survey web page, accessed January 7, 2020, at https://www.usgs.gov/ mission-areas/water-resources/science/flood-inundationmapping-fim-program?qt-science_center_objects=0\#qtscience_center_objects.

U.S. Geological Survey [USGS], 2020d, USGS surface-water data for the Nation, in USGS water data for the Nation: U.S. Geological Survey National Water Information System database, accessed January 3, 2020 at https://doi.org/ 10.5066/F7P55KJN. [Surface-water data directly accessible at https://waterdata.usgs.gov/nwis/sw.]

U.S. Geological Survey [USGS], 2020e, WaterAlert: U.S. Geological Survey web-based application, accessed March 20, 2020, at https://maps.waterdata.usgs.gov/mapper/ wateralert/. 
Yang, L., Jin, S., Danielson, P., Homer, C., Gass, L., Bender, S.M., Case, A., Costello, C., Dewitz, J., Fry, J., Funk, M., Granneman, B., Kiknes, G.C., Rigge, M., and Xian, G., 2018, A new generation of the United States National Land Cover Database - Requirements, research priorities, design, and implementation strategies: ISPRS Journal of Photogrammetry and Remote Sensing, v. 146, p. 108-123. [Also available at https://doi.org/10.1016/ j.isprsjprs.2018.09.006.]. 
For more information about this publication, contact: Director, USGS Central Midwest Water Science Center 1400 Independence Road

Rolla, MO 65401

573-308-3667

For additional information, visit: https://www.usgs.gov/centers/cmwater

Publishing support provided by the

Rolla Publishing Service Center 
